\title{
Sister chromatid exchange test detection of toxin-induced damage in cultured fish
}

\author{
J Lobillo, JV Delgado, A Rodero \\ Facultad de Veterinaria, Universidad de Córdoba, \\ Departamento de Genética, Avda Medina Azahara, 9, 14005 Córdoba, Spain \\ (Proceedings of the 9th European Colloquium on Cytogenetics of Domestic Animals; \\ Toulouse-Auzeville, 10-13 July 1990)
}

sister chromatid exchange (SCE) / genotoxicity / fish

\section{INTRODUCTION}

In recent years, industrial and agricultural toxic wastes in waters from the Guadalquivir Basin, Gulf of Cádiz and the Strait of Gibraltar have increased. This growing contamination has motivated our team to develop the cytogenetic sister chromatid exchange (SCE) test, with the aim of detecting the effects of these wastes on the autochthonous cultured and wild fish species of the Southern Atlantic off the coast of Spain.

The SCE test consists of the detection of increases in the normal mean number of sister chromatid exchanges in metaphase M2 cells. These cells are those which have undergone two rounds of replication in the presence of 5-bromodeoxyuridine (BrdU). The chromatic chromatid differentiation is easily detected by simple acridine orange staining or with the fluorescence plus Giemsa (FPG) technique.

\section{MATERIALS AND METHODS}

Fishes belonging to Rutilus alburnoides (Teleosteens Cyprinidae) and to Liza aurata (Teleosteens Mugilidae) species were used in this study because of their representativeness of the Southern Atlantic Spanish ichthyological fauna.

Four groups of individuals of these species were maintained in well-aerated aquaria at $25-27^{\circ} \mathrm{C}$. Forty-eight hours before sacrifice, they were injected ip with $0.5 \mathrm{mg}$ of phytohemagglutinin (PHA-M)/ $50 \mathrm{~g}$ of fish body weight. One dose $(0.8 \mathrm{mg}$ of $\mathrm{BrdU} / \mathrm{g}$ of fish) was injected directly into the cephalic kidney $24,22,20,16$ or $12 \mathrm{~h}$ before sacrifice, in order to obtain the maximum M2 cell (cells with sister chromatid differentiation) yield. Finally $0.3 \mu \mathrm{g}$ of colchicine per gram of fish was injected ip $2 \mathrm{~h}$ before sacrifice.

After sacrifice, the kidney was removed and macerated in $0.075 \mathrm{M} \mathrm{KCl}$ for $90 \mathrm{~min}$. The cell suspension was fixed in 5 changes of 1:3 acetic acid-methanol. 
Air-dried preparations were obtained and stained with acridine orange (Dutrillaux and Lejeune, 1973).

\section{RESULTS}

The BrdU treatment time which offered the maximum yield of $\mathrm{M} 2$ cells was $16 \mathrm{~h}$ for Rutilus alburnoides and $22 \mathrm{~h}$ for Liza aurata.

Figure 1 shows an M2 metaphase cell with 4 SCE. The image belongs to the first species of triploid nature.

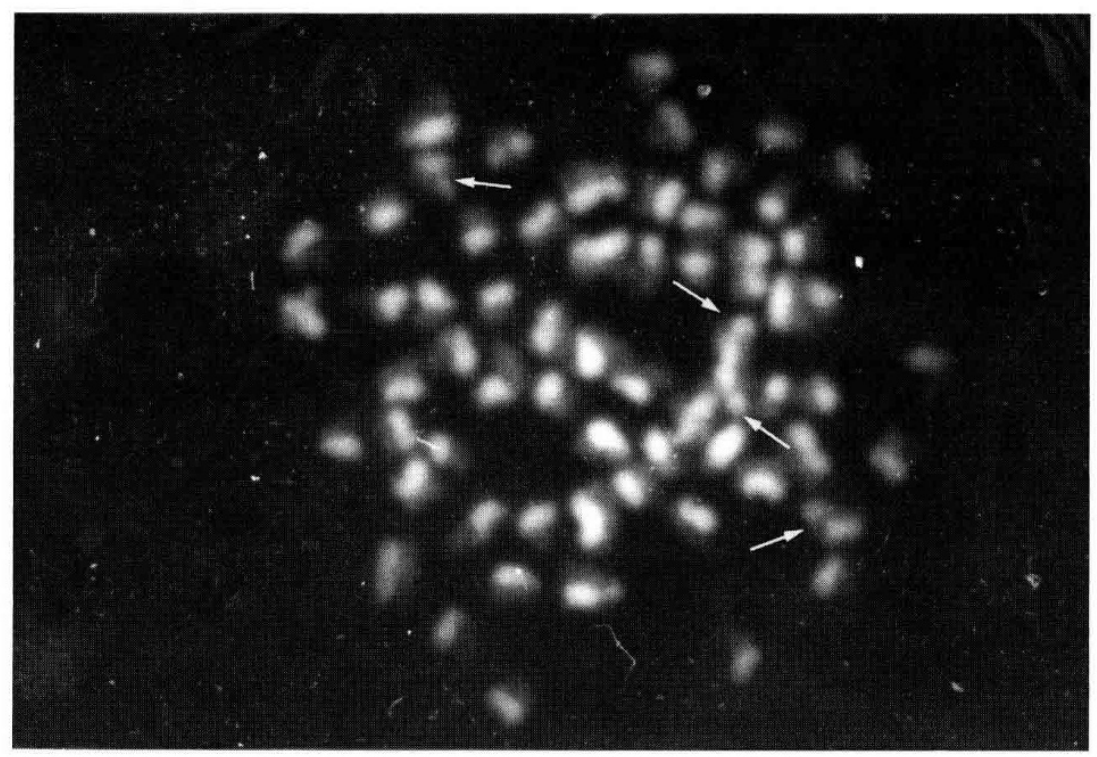

Fig 1. Triploid M2 metaphase cell of Rutilus alburnoides showing 4 SCE.

Mean SCE values for M2 metaphase cells were $3.57 \pm 0.59$ in Rutilus alburnoides and $2.91 \pm 0.43$ in Liza aurata. Table I summarizes the results of the SCE assay for M2 metaphase cells in both species.

Table I. Summarized results of SCE for metaphase cells in both species studied.

\begin{tabular}{cccccccccr}
\hline \multicolumn{1}{c}{ Species } & Tissue & $\begin{array}{c}\text { Tested } \\
\text { metaphases }\end{array}$ & \multicolumn{6}{c}{ SCE/metaphase } \\
\cline { 4 - 9 } & & & 0 & 1 & 2 & 3 & 4 & mean \\
\hline L alburnoides & $\begin{array}{l}\text { cephalic } \\
\text { kidney } \\
\text { aurata }\end{array}$ & 480 & 12 & 21 & 56 & 271 & 120 & 3.57 \\
& $\begin{array}{l}\text { cephalic } \\
\text { kidney }\end{array}$ & 160 & 8 & 17 & 44 & 69 & 22 & 2.81 \\
\hline
\end{tabular}




\section{DISCUSSION}

Although the meaning and mechanism of SCE is still unknown, it has been demonstrated that most of the genetically active chemical toxins (mutagens and/or carcinogens) induce significant increases in SCE when they are tested in in vivo animal systems or in vitro systems with activation (Stetka and Wolff, 1976; Carrano et al, 1978; Latt, 1982). At present, the SCE test is a very sensitive and rapid method for detecting chromosome mutagenicity and provides a powerful means of detecting environmental mutagens, as a complementary test to other tests of the same nature.

The application of BrdU incorporation to the detection of SCE in fish was used for the first time by Klingerman and Bloom (1976).

Since their report, other authors have used the detection of SCE as a sensitive cytogenetic test for determining chemically induced genetic damage, in in vivo (Alink et al, 1980; van der Hoeven et al, 1982; van der Kerkhoff and van der Gaag, $1985)$ and in vitro (Barker and Rackhan, 1979) systems.

In this study we established the mean number of SCE in fish maintained in high quality water, in the absence of toxins. This value constitutes the infrastructure of the SCE genotoxicity test, because any increase of this mean value in fish exposed to contaminated water indicates the presence in these waters of substances producing genetic damage. We are now testing the genotoxic activity of several agricultural pesticides whose results will be presented in the future.

\section{REFERENCES}

Alink GM, Frederix-Wolters EMH, van der Gaag MA, van der Kerkhoff JFJ, Poels CLM (1980) Induction of sister chromatid exchanges in fish exposed to Rhine water. Mutat Res $78,369-374$

Barker EM, Rackhan BD (1979) The induction of sister chromatid exchanges in cultured fish cells (Ameca esplendens) by carcinogenic mutagens. Mutat Res 68, 381-387

Carrano AV, Thompson LH, Lindl PA, Minklre JL (1978) Sister chromatid exchanges as an indicator of mutagenesis. Nature 271, 551-553

Dutrillaux B, Lejeune J (1973) Coloration des chromosomes humains par l'acridine orange après traitement par le 5-bromodésoxyuridine. CR Acad Sci Paris Ser D 3179-3180

Klingerman AD, Bloom SE (1976) Sister chromatid differentiation and exchanges in adult mudminnow (Umbra limi) after in vivo exposure to 5-bromodeoxyuridine. Chromosoma $56,101-109$

Latt SA (1982) Detection, significance and mechanism of sister chromatid exchange formation. Past experiments, current concept, future challenges. In: Sister Chromatid Exchange. (Wolff S, ed) John Wiley \& Sons, Inc, New York

Stetka DG, Wolff S (1976) Sister chromatid exchange as an assay for genetic damage induced by mutagen-carcinogen. I. In vivo test for compound requiring metabolic activation. Mutat Res 41, 333-342

van der Hoeven JCM, Brugeman IM, Alink GM, Koeman JH (1982) The killifish Nottobranchius rachowi, a new animal in genetic toxicology. Mutat Res $97,35-42$

van der Kerkhoff JFJ, van der Gaag MA (1985) Some factors affecting optimal differential staining of sister chromatids in vivo in the fish Notobranchius rachowi. Mutat Res 118, $61-68$ 